This is not the final version. The fully published version of Rindzeviciute, Egle (2020) Chernobyl as Technoscience. Technology and Culture, 61(4), pp. 1178-1187 CSociety for the History of Technology can be found at https://doi.org/10.1353/tech.2020.0117 


\title{
The Chernobyl Effect
}

\author{
Eglè Rindzevičiūtè
}

Dr Eglè Rindzevičiūtè is Associate Professor of Criminology and Sociology at Kingston University London. She is the author of The Power of Systems: How Policy Sciences Opened Up the Cold War World (Cornell University Press, 2016). Her book in progress, with the preliminary title Will to Predict: Orchestrating the Future, examines the politics and epistemology of prediction in late modern society. Dr Rindzevičiūte is the director and P.I. of the AHRC research networking project "Nuclear Cultural Heritage: From Knowledge to Practice" (2018-2020). She would like to thank the participants in the webinar (Re)Placing Chernobyl (14 May 2020), hosted by Kingston University and the FRINGE Centre for the Study of Social and Cultural Complexity, University College London, for their input in the discussion informing this analysis.

Released in 2019, the TV-miniseries Chernobyl has gripped viewers around the world. The five-part series tells the story of the 1986 disaster at the Chernobyl nuclear power plant in then Soviet-controlled Ukraine. In graphic detail it reveals the impact of the massive explosion and the fallout, on the people involved — from the thousands of plant workers living in the purpose-built city of Pripyat, the scientists and politicians, to the rescue workers who sacrificed their lives. Chernobyl topped the IMDB rankings as highest rated TV series and won many awards, including three Emmies. Scholars, writers, and journalists anatomized the series in their reviews in leading press outlets and academic journals. For the director, Johan Renck, Chernobyl was about human drama and emotions. ${ }^{1}$ For the writer, Craig Mazin, it was about the danger of lies and conspiracy and the search for truth. ${ }^{2}$ As with every influential work of art, however, the impact of Chernobyl exceeded the creators' aspirations and the work took on a life of its own. What does the popularity of Chernobyl, a story questioning the political management of an industrial accident in 1986, tell us about the current understandings of technoscience, a form of scientific knowledge that cannot be

\footnotetext{
${ }^{1}$ Renck, unpublished presentation.

2 The Chernobyl Podcast.
} 
separated from both technique and policy intervention? How does the series reflect on the power relations that shaped Soviet technoscience and in particular the nuclear industry? This essay does not scrutinize the film nor judge its accuracy, but maps the cultural imaginaries of Soviet and nuclear technoscience as they unfold.

\section{The Story of Chernobyl}

The eventful story of Chernobyl resonates strongly with the scholarly traditions of Soviet science and technology, based on a narrative approach: historians trace the great scientists, engineers, and inventors, by charting an innovation's discovery, adoption, and failure, while navigating conflicts between scientific, political, and cultural logics, including managing Cold War confrontation. ${ }^{3}$ This human and institutional actor-driven approach currently incorporates hybrid epistemologies, exploring the intersections of science and technology with social and cultural fields and their shaping by the agencies of the environment and manmade infrastructure. ${ }^{4}$ Scholars' environmental, digital, posthuman, and transnational changes of focus are also manifest in the re-examination of Soviet nuclearity, that relied on mining, computer simulation, urban planning, and cultural heritage-making. ${ }^{5}$

\section{The failure of diagnostic (non)knowledge}

In this context, the story of Chernobyl, I suggest, operates at two distinct levels: plots lines and representation. The entire plot centers around the failed attempts to approach the nuclear reactor's core and the ultimately successful attempts to approach the "truth," the reasons why the reactor failed catastrophically. The series culminates in the revelation of the ultimate

\footnotetext{
${ }^{3}$ Excellent studies include: Graham, What Have We Learned About Science and Technology; Holloway, Stalin and the Bomb; Josephson, Red Atom.

${ }^{4}$ Collier, Post-Soviet Social; Obertreis, "Imperial Desert Dreams;" Rindzeviciute, "Systems Analysis as Infrastructural Knowledge."

${ }^{5}$ For an extensive review, Guth et al., "Soviet Nuclear Technoscience." Also Brown, Plutopia; Storm, Krohn Andersson, and Rindzeviciute, "Urban Nuclear Reactors and the Security Theatre;" Rindzeviciute, The Power of Systems, Chapter 6.
} 
invisible: a view of the reactor from the inside as it exploded. Having watched the series three times, I was intrigued by the filmmakers' ability to move the plot forward in a way that holds the viewer's attention and keeps them in suspense, applying the same logic that underpins scientific epistemology: read correctly the signs of the unfolding reality (diagnosis), predict the consequences (prognosis) and act accordingly. ${ }^{6}$

In Chernobyl, the plot is driven by the constant failure of diagnosis and a political conflict over which diagnoses are recognised. In the first episode already, when a control room worker insists "The core has exploded," his manager tells colleagues: "He is in shock, get him out of here." But the information is not just dismissed, it is also ambivalent. The protagonists - residents of Pripyat, scientists, engineers, political administrators, physicians, miners, and the military — try to decode confusing signs, to understand what they are seeing, and to speculate about what they cannot see. In doing so, the protagonists rely on what they already know. This is not enough anymore: reality has just been changed. And a plethora of non-humans also makes up that reality: dogs, cows, birds, and lush flora alongside man-made infrastructures like the nuclear power plant, urban landscapes, offices, and homes. This heterogeneity, arguably inspired by Svetlana Alexievich's Chernobyl Prayer: Voices from Chernobyl (published in Russian in 1997, English translation in 2017), is stunning. The continually failing diagnosis leads to what Russian linguist Viktor Shklovskii describes as defamiliarization: habitual language and perceptual categories are abolished in an encounter with materiality "as if" for the first time. ${ }^{7}$ If for Shklovskii, defamiliarization is a resource and an aesthetic choice underpinning the technique of art, in Chernobyl it is a constraint on knowledge (which also drives the plot). People offer their speculations, scientists offer their expert evaluations, then in the next scene, the viewer is confronted with a turbulently

\footnotetext{
${ }^{6}$ Fidora, "Divination and Scientific Prediction."

${ }^{7}$ Shklovsky, "Art as Device."
} 
unfolding reality that refuses to conform with these diagnoses. Emergency response forces the changing reality into submission by trying to make it more predictable — for instance, in the air drop, when helicopters dropped thousands of tons of sand and boron on the core. However, unexpected consequences keep on emerging (melting core, radioactive cows and dogs). This is a lesson from experiencing technoscience in action: watch, listen, hypothesize, and then watch, listen, read all over again.

\section{Hybrid Nuclearity}

Nuclear technology thus defamiliarized is no longer confined to a sanitized laboratory space. It appears mundane, material, and networked. The nuclear power plant manifests as an entourage of administrators, operators, scientists, emergency response teams, and supporting infrastructures. In Chernobyl, however, the material infrastructure is more than just a stage setting for human drama: things, interiors, landscapes, and industrial sites convey strong messages. The reconfigured matter becomes an actant that absorbs the viewer: unremarkable surfaces burn a touching hand, a funeral involves pouring concrete into a grave. Moreover, the material dimension communicates the image of Soviet technoscience as a loser-or perhaps a hostage - in the Cold War race.

The film's visual aesthetic communicates the backwardness of Soviet technoscientific modernity in the eyes of the West, what was then the First world. Luminous light is reserved for nature (the sunny landscapes in Pripyat) and the Kremlin. The rest of the Soviet nuclear world where people live and work and the innards of the nuclear power plant, is submerged in gloom. This is not a slick, cosy Nordic noir style darkness, but an ill-lit world, which is "plausibly real" to the extent of being uncanny. No-one looks healthy, even the young 
characters. Many reviewers noted the painstaking attention to detail in the set designers' reconstruction of mundane 1986 Soviet society-though spotting a few inconsistencies, such as plastic window frames and school uniforms at weekends. This effect was achieved largely thanks to the local production team in Lithuania, where much of the series was filmed.

Lithuanian costume and set designers were able to source objects and locations appropriate to the period of late socialism, when the shortage-ridden economy was on the verge of collapse. In assembling Soviet material culture, they navigated between local memories and the film producers' expectations. For instance, the clothes were smart but slightly weird. Indeed, as the costume designer explained, men's clothes were often mismatched and the wrong size due to perennial shortages. In the late 1980 s, however, not everything was dilapidated — so the designers also included a few clean, new-looking fashionable items. ${ }^{8}$ Although nuclear scientists and engineers could enjoy comparatively privileged lifestyles, these were modest compared to Western middle-class professionals. Some commentators suggested that the main protagonist, an academician and deputy director of Kurchatov Institute, Valerii Legasov, who led the commission investigating the disaster, would have lived in a fancier apartment, but then even leading physicist Petr Kapitsa complained that a decent suit cost more than an elite scientist could comfortably afford. ${ }^{9}$ Indeed, having an apartment, however dilapidated or small, was already a sign of privilege. ${ }^{10}$

The impression of authenticity and the "realism" of the nuclear technology's social and political worlds are not only down to detailed ethnography, but also the use of cinematic language. Cinematographic realism, according to the film theorist Michael Goddard, is an arrangement of accepted visual culture regimes. The perception of an image as realistic can change with shifts in visual culture. Goddard suggests that Chernobyl's "realist" presentation

\footnotetext{
${ }^{8}$ Kalinkaitè-Matuliauskienè, "Serialo 'Černobylis' užkulisiai."

${ }^{9}$ Rindzeviciute, The Power of Systems, 105.

${ }^{10}$ Rogacheva, The Private World of Soviet Scientists.
} 
of technology drew on the typical film sets that used East European industrial infrastructures shrouded in dust, like in Andrei Tarkovsky's Stalker (1979), filmed on an abandoned industrial site in Estonia, but also the labyrinth of underground canals in Andrzej Wajda's Canal (1956), or the austere urban districts in Krzysztof Kieślowski’s Dekalog (1988). ${ }^{11}$ Chernobyl's human protagonists get their hands dirty, both in terms of regular dirt, blood, and radioactive contamination. The association of dirt with danger ties in with the enlightenment tradition that has imposed high standards of cleanliness as a symbol of progress and rational modernity. ${ }^{12}$ To show that Soviet high-tech modernity is not there yet, the character Anatolii Diatlov is shown smoking in the control room. The inability to get labs clean, as communication sociologist Manuel Castells has described, kept the Soviets away from what Castells and Kiselyova saw as the genuine information age. ${ }^{13}$ As STS scholar of Soviet and American nuclear power Kate Brown noted, however, the Western capitalist imaginary of Soviet nuclear and medical institutions often mistook the dilapidated infrastructure and outdated technical equipment for a lower level of expertise; this, as historians have shown, was not always the case. ${ }^{14}$ The series also verifies that fact: in Episode 2, physicist Ulana Khomiuk is introduced sleeping on her desk in an office that has seen better days, yet her laboratory equipment enables her to interpret the signs correctly.

Whereas Soviet material culture appears familiar and authentic through established representation, what about Soviet power relations? A significant scholarship theme is the tension between political ideology and "proper" science. As I have argued elsewhere, much historiography of Soviet science was based on the divide between politicized and pure technoscience. Once this divide was transgressed, someone had to pay the price. Examples of

\footnotetext{
${ }^{11}$ Goddard, unpublished presentation.

12 Joyce, The Rule of Freedom.

${ }^{13}$ Castells and Kiselyova, The Collapse of Soviet Communism.

${ }^{14}$ Brown, Manual for Survival; Storm, Post-Industrial Landscape Scars; Schmid, Producing Power.
} 
politicized science include myth-makers like biologist and agronomist Lysenko, the controversial "dictator" of Communistic biology during Stalin's regime; also the technological failures and high human and environmental costs of gigantic industrial projects such as at the notorious heavy industries cities of Magnitogorsk, with its polluting iron and steel works, and Norilsk, where an ongoing industrial disaster is flooding local rivers in Russia with thousands of tonnes of diesel oil not to mention the $\mathrm{SO} 2$ and other emissions in the atmosphere. ${ }^{15}$ The examples of pure technoscience, both abstract and applied, such as fundamental mathematics, theoretical physics, linguistics, computer science, and cybernetics, enjoy an "isles of freedom" status such as special institutes where elite knowledge and technology workers practice alternative, more liberal lifestyles. ${ }^{16}$ Curiously, the idea that politics and science could legitimately mix and co-produce each other seemed to be restricted to liberal democracies. ${ }^{17}$ Recent scholarship argues that in Soviet authoritarian modernity, new scientific epistemological standards co-evolving with new individual and institutional agencies, produced new politics. This assumed different degrees of "liberalism": selfregulation, critical deliberation, and autonomization.

I would like to suggest that the plot developed in Chernobyl resonates with this paradigm of an emerging "liberal," science-driven, and open society. According to philosopher of science Karl Popper's classic tenet, the process of testing and falsifying a hypothesis is fundamental for distinguishing the scientific method from common sense. The danger arises when the scientific falsification and rigorous scrutiny become an organizational ritual. This is what happened at Chernobyl as showed by the series and in reality: an inappropriate reactor shutdown test was carried out to cover up management flaws. Amplifying this wrongdoing is the political use of technoscience as a symbol of progress and power. Inconvenient information

\footnotetext{
${ }^{15}$ Josephson, "'Projects of the Century' in Soviet History."

${ }^{16}$ Gerovitch, "We Teach Them to Be Free;" Weiner, A Little Corner of Freedom.

${ }^{17}$ Mayr, Authority, Liberty, and Automatic Machinery; Otter, The Victorian Eye.
} 
was suppressed: facts about the flaws in the reactor's design were not made available to operators. When these facts were revealed, the consequences for those who disrupted the political veneer of "technology under control" were grave: in the film, this was illustrated by Legasov's suicide, a real life event that two years after Chernobyl.

While this argument, summarized in Mazin's "what is the cost of lies," is undoubtedly plausible and widely evidenced, it does not exhaust the complexity of the Soviet technoscientific assemblage. Chernobyl's imaginary geography is curiously confined and claustrophobic in the extreme. The viewer can see inside the Politburo and even inside the exploding reactor, but the West is not revealed. Instead, the West exists in whispers, in secondary reports of public and diplomatic reactions. This informational isolation resonates with the narrative of the Soviet anomaly and the awkward relationship between Soviet and liberal technoscience scholarship. The film misses the extent to which Soviet scientists participated in international projects. However, this is not surprising, because the history of Soviet technoscience has been long written as a form of liberal critique of the authoritarian regime and not as an integral part of the "universal" narrative and analytical framework ofpower, society and knowledge.

\section{Not a Soviet Other}

This integration is emerging in science diplomacy and environmental history, particularly in studies of technology transfer and mitigating the negative impact of industrial development. In Chernobyl, science diplomacy enters as part of the clean-up action, a give-and-take effort to obtain superior Western machinery while repairing the reputational damage of a great power (Episode 4). The Soviet authorities were notorious for withholding data regarding public health, demography, economics, natural resources, environmental pollution, and 
nuclear tests: Western and local scientists alike criticized this practice. ${ }^{18}$ Soviet scientists benefited from scientific diplomacy as it helped them obtain their own Soviet data via international and transnational institutions such as the International Atomic Energy Agency (IAEA), the International Institute of Applied Systems Analysis (IIASA), United Nations programs, non-governmental scientific associations, and policy issue networks. The Chernobyl disaster happened when Soviet-U.S. cooperation in the nuclear winter study, a computer simulation of the environmental effects of nuclear war, was nearing completion (1983-1986). Prominent scientists,such as the pro-nuclear physicist Evgenii Velikhov and the anti-nuclear mathematician Nikita Moiseev, who led this research, also engaged in Chernobyl's clear up procedures. ${ }^{19}$ While, in 1990, Moiseev was critical of nuclear power and called for wide-scale international scientific monitoring of the consequences of Chernobyl, Velikhov did not change his position towards nuclear reactors like Chernobyl or the future of nuclear power. ${ }^{20}$ This is just one example of the international context overlooked in the film. That this is not mentioned sends a very strong message that knowledge between the Cold War blocs of East and West flowed only one-way, with the West scrutinizing the underperforming East. We know this was not the case. ${ }^{21}$

The long-established dualisms of science-politics and nature-culture appeared to melt in the disaster on the ground. As Gregory Dufaud writes insightfully, although dualist categories have become suspect in science and technology studies, a focus on dualisms can be productive to historicize Soviet technoscience, particularly as an object of historical

\footnotetext{
${ }^{18}$ Petryna, Life Exposed; Kuchinskaya, The Politics of Invisibility; Kasperski, "From Legacy to Heritage."

${ }^{19}$ Velikhov was upset about how Soviet secrecy was portrayed in the film Chernobyl, insisting that no data was hidden. Panteleeva, "Akademik Velikhov."

${ }^{20}$ Moiseev and Barenboim, "The Chernobyl Environmental Problems."

${ }^{21}$ On history of science diplomacy, see Araphostatis and Laborie, "Governing Technosciences in the Age of Grand Challenges."
} 
critique. ${ }^{22}$ The scientific and political autonomy of nuclear physicists should be re-examined in light of research on the practical heteronomy of nuclear engineers, entangled in the social, material and technical realities of power plants, their mundane operations, and organizational politics. ${ }^{23}$ The space between Soviet regime support and opposition should also be approached with a sociological sensibility. Soviet organizations had a specific institutional logic and Albert Hirschman's work can explain their (dys)functioning. Also, a focus on organizational narratives and sense-making, according to Barbara Czarniawska, could clarify the range of scientists' responses to Chernobyl. ${ }^{24}$ From health care to the military, many administrations had their own cultures and practices that scholars are only beginning to unlock, like Kate Brown in her Manual for Survival (2019). Chernobyl's characters who spoke truth to power might no longer appear as much of an aberration as Russian-American journalist Masha Gessen perceived. ${ }^{25}$ Rather, they expressed what science and technology historian Slava Gerovitch calls the impossible contradiction the Soviet ideology imposed on scholars and engineers: "to be obedient state servants and, at the same time, to show creativity and independence of thought." 26

It is the public impact of Chernobyl that is questioning the idea that the Soviet experience is an anomaly. If this were the case, why has Chernobyl succeeded so well in bringing back the nuclear problematique to social debates globally, in the context of a deepening public indifference to the nuclear risk? The problems that Soviets faced in nuclear technology speak to current public sensibility, because they resonate with viewers' experience of uncertainty regarding public and official "truths" and the power of science to provide ultimate solutions.

\footnotetext{
22 Dufaud, "The History of Science and Technology."

${ }^{23}$ Wendland, "Nuclearizing Ukraine - Ukrainizing the Atom."

${ }^{24}$ Hirschman, Exit, Voice, and Loyalty; Czarniawska, A Narrative Approach to Organization Studies.

${ }^{25}$ Gessen, "What HBO's 'Chernobyl' Got Right."

${ }^{26}$ Gerovitch, "We Teach Them," 720.
} 
While Chernobyl revealed many things, some debatable, it did make one point very clear: Soviet history is not just a history of liberal democracy's Other, it is part of our entangled relationship with technoscience. 


\section{Bibliography}

Araphostatis, Statis and Leonard Laborie. "Governing Technosciences in the Age of Grand Challenges: A European Historical Perspective on the Entanglement of Science, Technology, Diplomacy, and Democracy." Technology and Culture 61, no. 1 (2020) 318-332.

Brown, Kate. Manual for Survival: A Chernobyl Guide to the Future. New York: Norton \& Co, 2019.

Brown, Kate. Plutopia: Nuclear Families, Atomic Cities and the Great Soviet and American Plutonium Disasters. Oxford: University Press, 2013.

Castells, Manuel and Emma Kiselyova, The Collapse of Soviet Communism: A View from the Information Society. Berkeley: International and Area Studies, University of California at Berkeley, 1995.

Czarniawska, Barbara. A Narrative Approach to Organization Studies. London: Sage, 1998.

Collier, Stephen. Post-Soviet Social: Neoliberalism, Social Modernity, Biopolitics. Princeton, NJ: Princeton University Press, 2011.

Dufaud, Gregory. "The History of Science and Technology, or How to Grasp Heterogeneity." Kritika 20, no. 4 (2019) 813-822.

Fidora, Alexander. "Divination and Scientific Prediction: The Epistemology of Prognostic Sciences in Medieval Europe.” Early Science and Medicine 18, no. 6 (2013) 517-535.

Gerovitch, Slava. "We Teach Them to Be Free" Specialized Math Schools and the Cultivation of the Soviet Technical Intelligentsia." Kritika 20, no. 4 (2019): 717-754. 
Gessen, Masha. "What HBO’s 'Chernobyl' Got Right and What It Got Terribly Wrong." The New Yorker (4 June 2019), available online: https://www.newyorker.com/news/ourcolumnists/what-hbos-chernobyl-got-right-and-what-it-got-terribly-wrong

Goddard, Michael. An unpublished presentation at a webinar (Re)Placing Chernobyl, Kingston University and the UCL, 14 May 2020. Available online: https://youtu.be/Itn0-OhzSBg

Graham, Loren. What Have We Learned About Science and Technology from the Russian Experience? Stanford: Stanford University Press, 1998.

Guth, Stefan et al. "Soviet Nuclear Technoscience: Topography of the Field and New Avenues of Research.” Cahiers du monde Russe 60, no. 23 (2019): 257-280.

Hirschman, Albert. Exit, Voice, and Loyalty: Responses to Decline in Firms, Organizations, and States. Cambridge, MA: Harvard University Press, 1972.

Holloway, David. Stalin and the Bomb: The Soviet Union and Atomic Energy, 1939-1956. New Haven: Yale University Press, 1996.

Josephson, Paul. Red Atom. Pittsburgh: University of Pittsburgh Press, 2005.

Josephson, Paul R. “'Projects of the Century' in Soviet History: Large Scale Technologies from Lenin to Gorbachev.” Technology and Culture 36, no. 3 (1995): 519-559.

Joyce, Patrick. The Rule of Freedom: Liberalism and the Modern City. London \& New York: Verso, 2003.

Kalinkaitè-Matuliauskienė, Vaida. "Serialo ‘Černobylis' užkulisiai: lietuvių kūrèjai turèjo aiškinti apie deficitą ir kodèl prie mokyklos negali būti tvoros," Lrt.lt (September 27, 2019) https://www.lrt.lt/naujienos/gyvenimas/13/1100251/serialo-cernobylis-uzkulisiailietuviu-kurejai-turejo-aiskinti-apie-deficita-ir-kodel-prie-mokyklos-negali-buti-tvoros . 
Kasperski, Tatiana. "From Legacy to Heritage: The Changing Political and Symbolic Status of Military Nuclear Waste in Russia." Cahiers du monde Russe 60, no. 2 (2019): 517 538.

Kuchinskaya, Olga. The Politics of Invisibility: Public Knowledge about Radiation Health Effects after Chernobyl. Cambridge, MA: MIT Press, 2014.

Mayr, Otto. Authority, Liberty, and Automatic Machinery in Early Modern Europe. Baltimore: Johns Hopkins University Press, 1986.

Moiseev, Nikita, and G. Barenboim. "The Chernobyl Environmental Problems," Planetary Emergencies, 10th International Seminar on Nuclear War, Erice, Italy, August, 1990.

Obertreis, Julia. Imperial Desert Dreams: Cotton Growing and Irrigation in Central Asia, 1860-1991. Vandenhoeck \& Ruprecht Gmbh \& Co, 2017.

Oevermann, Heike and Eszter Gantner, editors, Urban Heritage: Agents, Access, and Securitization. London and New York: Routledge, 2019.

Otter, Chris. The Victorian Eye: A Political History of Light and Vision in Britain, 18001910. Chicago: University of Chicago Press, 2008.

Panteleeva, Nadezhda. “Akademik Velikhov: Amerikanskii fil'm 'Chernobyl'”- polnaia erunda.” Ekspress gazeta (24 June 2019), https://www.eg.ru/society/746782-akademikvelihov-amerikanskiy-film-171 chernobyl187-8212-polnaya-erunda-055961/

Petryna, Adriana. Life Exposed: Biological Citizens after Chernobyl. Princeton: University Press, 2002.

Renck, Johan. An unpublished presentation at a webinar (Re)Placing Chernobyl, Kingston University and the UCL, May 14, 2020. Available online: https://youtu.be/Itn0-OhzSBg 
Rindzevičiūtè, Eglè. "Systems Analysis as Infrastructural Knowledge: Scientific Expertise and Dissensus under State Socialism." History of Political Economy 51, no. S1 (2019): 204-227.

Rindzevičiūtè, Eglè. The Power of Systems: How Policy Sciences Opened Up the Cold War World. Ithaca: Cornell University Press, 2016.

Rogacheva, Maria. The Private World of Soviet Scientists: From Stalin to Gorbachev. Cambridge: Cambridge University Press, 2017.

Schmid, Sonja D. Producing Power: The pre-Chernobyl History of the Soviet Nuclear Industry. Cambridge, MA: MIT Press, 2015.

Shklovsky, Viktor. “Art as Device” (1917/1919). In Alexandra Berlina, editor, Viktor Shklovsky: A Reader, 73-96. London: Bloomsbury, 2017.

Storm, Anna, Fredrik Krohn Andersson, Eglè Rindzevičiūtė. "Urban Nuclear Reactors and the Security Theatre: The Making of Atomic Heritage in Chicago, Moscow and Stockholm.”

Storm, Anna. Post Industrial Landscape Scars. New York: Palgrave, 2014.

The Chernobyl Podcast. Available online: https://podcasts.apple.com/us/podcast/thechernobyl-podcast/id1459712981

Weiner, Douglas R. A Little Corner of Freedom: Russian Nature Protection from Stalin to Gorbachev. Berkeley: University of California Press, 1999.

Wendland, Anna Veronika. "Nuclearizing Ukraine - Ukrainizing the Atom. Soviet Nuclear Technopolitics, Crisis, and Resilience on the Imperial Periphery." Cahiers du monde Russe 60, no. 2 (2019) 335-368. 